\title{
Active faulting within a megacity: the geometry and slip rate of the Pardisan thrust in central Tehran, Iran
}

\author{
M. Talebian, ${ }^{1}$ A.C. Copley, ${ }^{2}$ M. Fattahi, ${ }^{3}$ M. Ghorashi, ${ }^{1}$ J.A. Jackson, ${ }^{2}$ H. Nazari, ${ }^{1}$ \\ R.A. Sloan ${ }^{4}$ and R.T. Walker ${ }^{5}$ \\ ${ }^{1}$ Research Institute for Earth Sciences, Geological Survey of Iran, Meraj Avenue, Azadi Square, Tehran, Iran.E-mail: morteza.talebian@gmail.com \\ ${ }^{2}$ COMET, Bullard Laboratories, Cambridge University, Madingley Road, Cambridge CB3 0EZ, United Kingdom \\ ${ }^{3}$ Institute of Geophysics, University of Tehran, Tehran, Iran \\ ${ }^{4}$ Department of Geological Sciences, University of Cape Town, Rondesbosch 7701, South Africa \\ ${ }^{5}$ COMET, Department of Earth Sciences, Oxford University, South Parks Road, Oxford OX1 3AN, United Kingdom
}

Accepted 2016 September 16. Received 2016 September 14; in original form 2016 May 18

\begin{abstract}
SUMMAR Y
Tehran, the capital city of Iran with a population of over 12 million, is one of the largest urban centres within the seismically active Alpine-Himalayan orogenic belt. Although several historic earthquakes have affected Tehran, their relation to individual faults is ambiguous for most. This ambiguity is partly due to a lack of knowledge about the locations, geometries and seismic potential of structures that have been obscured by dramatic urban growth over the past three decades, and which have covered most of the young geomorphic markers and natural exposures. Here we use aerial photographs from 1956, combined with an $\sim 1 \mathrm{~m}$ DEM derived from stereo Pleiades satellite imagery to investigate the geomorphology of a growing anticline above a thrust fault — the Pardisan thrust - within central Tehran. The topography across the ridge is consistent with a steep ramp extending from close to the surface to a depth of $\sim 2 \mathrm{~km}$, where it presumably connects with a shallow-dipping detachment. No primary fault is visible at the surface, and it is possible that the faulting dissipates in the near surface as distributed shearing. We use optically stimulated luminescence to date remnants of uplifted and warped alluvial deposits that are offset vertically across the Pardisan fault, providing minimum uplift and slip-rates of at least $1 \mathrm{~mm} \mathrm{yr}^{-1}$. Our study shows that the faults within the Tehran urban region have relatively rapid rates of slip, are important in the regional tectonics, and have a great impact on earthquake hazard assessment of the city and surrounding region.
\end{abstract}

Key words: Geomorphology; Seismicity and tectonics; Neotectonics.

\section{INTRODUCTION}

Tehran, with a population of more than 12 million, has experienced a rapid increase in population over the last three decades to become one of the largest cities in the Middle East. The urbanization has occurred against a backdrop of continual earthquake hazard (Ambraseys \& Melville 1982; Berberian \& Yeats 1999). Historical earthquakes in 958 A.D., 1665 A.D., and 1830 A.D. had epicentral regions centred on the Mosha and Taleghan strike-slip faults to the north of the city, and presumably occurred on these or other nearby structures (e.g. Fig. 1; Ambraseys \& Melville 1982; Berberian \& Yeats 1999; Nazari et al. 2009; Ritz et al. 2012). However, earthquakes in 312-280 B.C., 855 A.D., 1177 A.D. were located further south, within the Tehran plain, and their sources are not known with certainty, although palaeoseismic events on the North Tehran Fault (NTF; Ritz et al. 2012; Fig. 1) have been suggested as the sources of 312-280 B.C. and 1177 A.D. events. All three earthquakes caused destruction in the old city of Rey (Ambraseys \&
Melville 1982; Berberian \& Yeats 1999; Fig. 1b), which is located within the southern suburbs of modern Tehran, and any similar events in future would cause heavy damage to Tehran.

Although faults and folds within Quaternary alluvial deposits of the Tehran plain were initially recognized in the 1950s (Rieben 1955), and have been the subject of multiple later studies (e.g. Tchalenko et al. 1974; Berberian 1976; Berberian et al. 1985; Abbassi \& Farbod 2009; Landgraf 2010; Solaymani Azad et al. 2011), the expansion of the city over the last few decades has largely prevented characterization of the large-scale geomorphology, with recent studies focusing mainly on small-scale structural features exposed in road cuts, quarries and excavations made for building foundations.

In this paper, we present geomorphic evidence of a hidden fault in the central part of Tehran - the Pardisan thrust - applying the increased understanding on the relationship between surface folding and faulting that has come from detailed forensic studies of recent reverse faulting earthquakes within Iran and surroundings (e.g. 


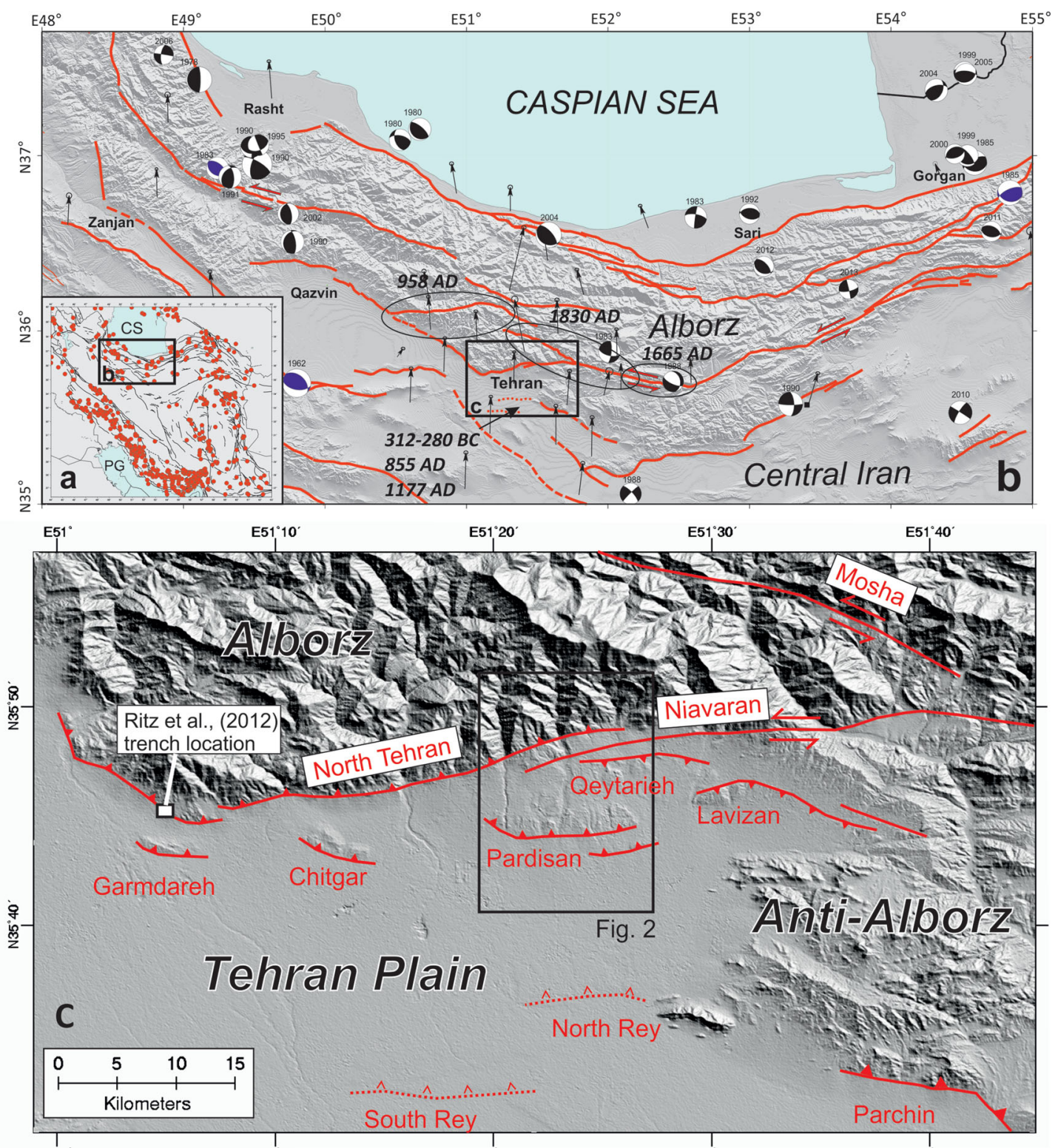

Figure 1. (a) Map of Iran showing earthquakes from the catalogue of Engdahl et al. (1998). (b) Active faulting of the Alborz Mountains and the region around Tehran. The epicentral zones of historical earthquakes in 958 A.D., 1665 A.D. and 1830 A.D. are represented by black ellipses. The macroseismic epicentres of earthquakes in 312-280 B.C., 855 A.D. and 1177 A.D. are not well resolved, but caused damage in the city of Rey (southern Tehran). (c) SRTM3 digital topography of the Tehran plain with active faults drawn in red, based on existing works (as referenced in the main text), compiled and refined by our own analysis. The region shown in Fig. 2 is boxed. The North and South Rey scarps are dotted due to uncertainty about whether they are formed by faulting.

Berberian et al. 1999; Talebian et al. 2004; Walker 2006; Walker et al. 2010, 2013; Copley 2014; Copley \& Jolivet 2016; Mackenzie et al. 2016). To examine the geomorphology we combine an interpretation of the landscape from old aerial photographs with an analysis of a high-resolution digital elevation model (DEM) that we generate from sub-metre stereo satellite imagery. The DEM is of sufficiently high resolution that we can make detailed topographic measurements across the fold and fault despite the urban cover. We also present the results of optically stimulated luminescence (OSL) dating on a rare exposed remnant of uplifted alluvial deposits in the hanging-wall, enabling us to estimate a rate of uplift. The existence of the Pardisan fault (which has also been called the Milad Tower thrust or foreberg in some studies) has previously been acknowledged (e.g. Jackson 2008; Abbassi \& Farbod 2009; Landgraf 2010; Nazari et al. 2010; Ritz et al. 2012), but our present study presents the first detailed geomorphic analysis and estimate of its slip-rate. The OSL samples analysed in our study were collected in 2008 , shortly before the exposures in the vicinity were completely masked or destroyed by urban activities.

\section{TECTONIC AND GEOLOGIC SETTING}

\subsection{Regional tectonics}

Tehran lies at the foot of the Alborz belt, which is a seismically active region to the south of the Caspian Sea. The tectonic activity in the Alborz mountain range is caused both by the northward convergence of central Iran toward Eurasia, and also by the northwestward motion of the South Caspian Basin with respect to Eurasia (e.g. Jackson et al. 2002; Ritz et al. 2003, 2006; Copley \& Jackson 2006; Djamour 

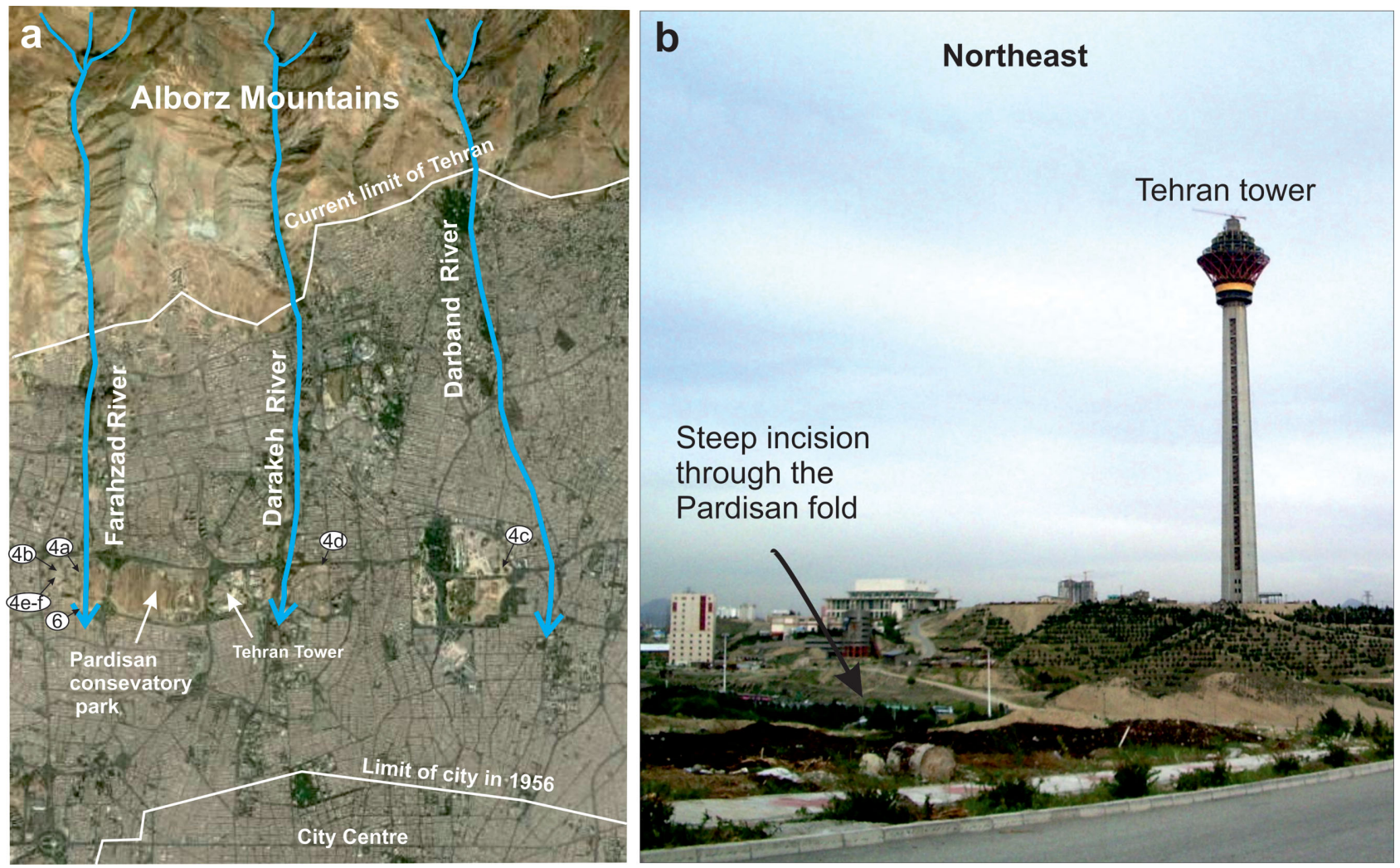

Figure 2. (a) Landsat satellite image (from GoogleEarth) showing northern Tehran and the southern edge of the Alborz Mountains. A series of parks are aligned along the Pardisan fold, which is otherwise now largely covered by buildings. The approximate city limit in 1956 is shown. Three main south-flowing rivers cross the Pardisan fold, with their courses marked by blue lines. The blue arrows are roughly in line with the escarpment at the southern margin of the Pardisan fold, which is also the southern limit of the river incision. Our field study is focused on the Farahzad River. (b) Photograph of the Tehran (Milad) tower showing the steep incised topography within the southern part of the Pardisan fold.

et al. 2010; Mousavi et al. 2013). Oblique shortening in the Alborz is taken up by left-lateral strike slip faults within the interior of the range, and distributed thrusting on the northern and southern margins. The range is therefore being deformed by strain partitioning of the oblique shortening onto range-parallel left-lateral strike-slip and thrust faults (Jackson et al. 2002; Allen et al. 2003). The thrusts on the northern side principally dip to the south, whereas those in the south dip northwards (Stöcklin 1974). Frontal structures encroach upon the adjacent foreland basins: the South Caspian Basin in the north and along a less linear topographic front at the southern margin (Allen et al. 2003). To the South, deformation seems to extend beyond the piedmont area (Vernant et al. 2004). Present day N-S shortening and left-lateral shear across the Alborz occurs at $5 \pm 2$ $\mathrm{mm} \mathrm{yr}^{-1}$ and $4 \pm 2 \mathrm{~mm} \mathrm{yr}^{-1}$, respectively (Vernant et al. 2004; Djamour et al. 2010).

\subsection{Active faulting in the Tehran region}

The NTF is a thrust that separates fluvial deposits of the Tehran plain from older, mostly Eocene, rocks of the central Alborz and defines the northern limit of the city (Figs 1 and 2). It appears that the NTF experienced an early period of dextral shear, which was superseded by sinistral-oblique thrusting associated with NE-oriented shortening (Landgraf et al. 2009). The surface trace of the NTF extends for about $70 \mathrm{~km}$ between $\sim 51^{\circ} 05^{\prime} \mathrm{E}$ and $\sim 51^{\circ} 50^{\prime} \mathrm{E}$. East of Tehran, it merges with the Mosha active left-lateral strike-slip fault (e.g. Solaymani Azad et al. 2011; Ghassemi et al. 2014). Ritz et al. (2012) uncovered six or seven surface-rupturing events on the western NTF within the last $\sim 30 \mathrm{ka}$, with magnitudes that they estimate at 6.1 to 7.2 , and an average slip-rate of $\sim 0.3 \mathrm{~mm} \mathrm{yr}^{-1}$. They state that the two most recent events in their trench may correspond to the 312-280 B.C. and 1177 A.D. historical earthquakes. See Fig. 1 for their trench location.

The eastern extent of present-day activity on the NTF is debated. From a study near the eastern end of the NTF, Trifonov et al. (1996), concluded that activity stopped by the Mid-Late Pleistocene. They also conclude that a fault system south of the NTF (the Niavaran fault, Figs 1 and 3) is younger. Abbassi \& Farbod (2009), and Solaymani Azad et al. (2011) also suggest that the eastern NTF is inactive, with activity now transferred southwards to the Niavaran fault.

Several structures are visible in the alluvial plain $\sim 5-10 \mathrm{~km}$ south of the NTF and Niavaran faults (Fig. 1). The Lavisan and Qeytarieh anticlines are the easternmost of these structures. The anticlines correspond to elongate NNW-SSE ranges of low hills, which have steep escarpments on their northern margins. Geological cross-sections show asymmetric folding, with steep northern limbs and gently dipping southern limbs. The Pardisan anticline (the focus of our paper) is the next fold segment to the west, and has an overall vergeance to the south (see details in Section 3). Further west, the Chitgar and Garmdareh anticlines are manifest in the landscape as ranges of low hills (Fig. 1). The folds appear to be in a left-stepping en-echelon arrangement, which may indicate a component of leftlateral strike slip across the zone of folding (e.g. Abbassi \& Farbod 2009).

The eastern margin of the Tehran plain is defined by the AntiAlborz range-front, whose southern edge is bounded by the Parchin active thrust (Fig. 1). A series of subparallel south-facing scarps (the 

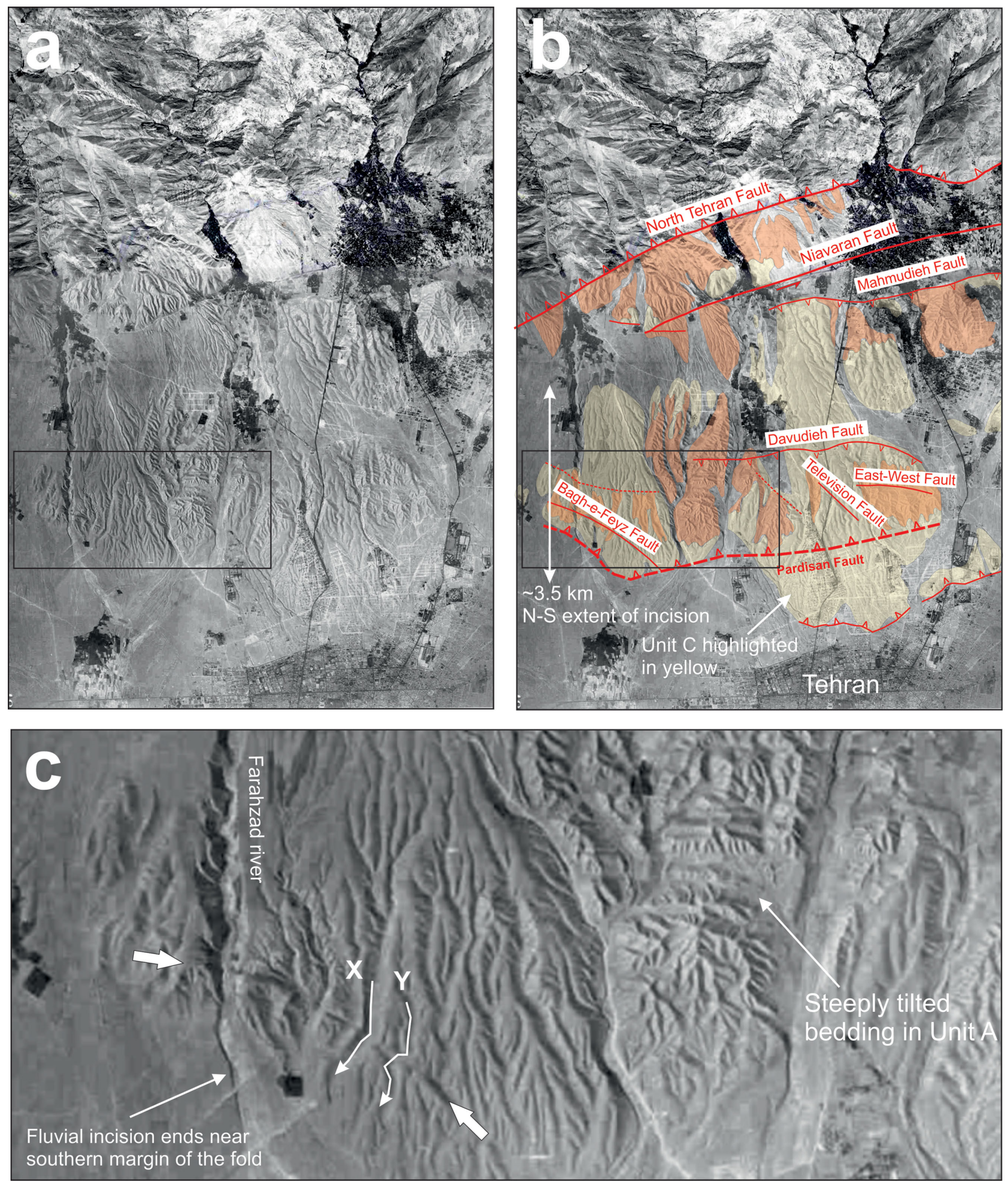

Figure 3. (a) Aerial photograph from the 1956 nationwide survey, prior to northward expansion of Tehran city. The panel shows the same approximate region as in Fig. 2, see Fig. 1(a) for location within the wider region. (b) Geomorphic and structural interpretation. The north Tehran thrust follows the Alborz range-front. Warping and incision of Quaternary alluvium in the Tehran plain is controlled by the Pardisan fault, along with several other north- and south-dipping thrusts. The hanging-wall of the Pardisan fault is cut by several minor fault scarps, as well as the left-lateral Niavaran fault. Incision of the Tehran Fm. (Unit C, highlighted in yellow) alluvial fans extends $\sim 3.5 \mathrm{~km}$ north of the Pardisan fault. Areas where Units A and B outcrop are highlighted in orange. (c) Close-up of warped alluvial surfaces at the southwest of the Pardisan fault, where it is crossed by the Farahzad river. The amount of river incision decreases abruptly across the fold margin, and ends completely within a few hundred metres. The immediate hanging-wall of the fault is cut by the NW-SE trending Bagh-e-Feyz fault, with uplift to the SW, and an apparent right-lateral component of slip, as shown by apparent displacement of small streams (X and Y) across the scarp. 
North and South Rey scarps, Fig. 1c, and the Kahrizak scarps, sited south of the area shown in Fig. 1c) are present along strike to the west of the Parchin thrust, within the alluvial Tehran plain. Nazari et al. (2010) inferred an absence of activity on all three of these scarps from the lack of deformation of sediment layers exposed in trenches across the scarps. They instead interpret the scarps as palaeolake shorelines. However, the east-west Kahrizak scarp has also been described as an active fault by De Martini et al. (1998), who identified Quaternary displacements within a trench exposure. Additional active faults are likely to exist within the interior of the Anti-Alborz.

\subsection{Quaternary stratigraphy of the Tehran plain}

The first report to describe and classify the alluvial deposits and geological structure of the Tehran plain was published by Rieben (1955), who assigned the exposed alluvial deposits to four units from A (the oldest) to D, and mapped a series of folds within the plain in his cross-sections. Engalenc (1968) provided a more detailed map of alluvial deposits, and also drew attention to the strike-slip faults north of Tehran. Below, we describe the Quaternary units in detail. In later sections, we use the A-D nomenclature of Rieben (1955) in describing the different units.

Unit A (also known as the Hezardareh formation) is the oldest and thickest of the deposits, with up to 1000 m exposed mainly throughout higher hills to the northeast of Tehran or in the ravines and roads crossing anticlinal cores within the city. It rests unconformably on Miocene red beds or Eocene volcanic rocks. Stöcklin \& Setudehnia (1977) suggested a possible Pliocene or Plio-Pleistocene age for the A formation. The main identifying characteristics of the Unit A are the regularity of its bedding, cementation by lime carbonates and pale grey hue with pebbles originated from the older rocks in Alborz (Rieben 1955). The Hezardareh Fm. lies unconformably under younger alluvial/fluvial deposits of Units B, C or D. On the southern flank of the Pardisan anticline, the $A$ unit is almost vertical and rests discordantly under $\mathrm{C}$ deposits, while on the northern flank it is covered by sediments of the B formation.

The Kahrizak, or Unit B, formation refers to laterally heterogeneous deposits that overlie the Hezardareh Fm. deposits. The unit consists of sandy or clayey loam with patches of gravel and numerous elongated concretions, while to the north it starts with basal conglomerate and contains large boulders. The Kahrizak deposits are exposed within the ravines cutting the Pardisan anticline and road cuts to the north of the ridge, where they are tilted to the north.

The Tehran, or C, formation is an alluvial conglomerate that is characterized by its regular stratification and red laterite crusts. This formation is mostly found in excavations for building foundations, and is also encountered as palaeovalley fill within older topographic structures. The upper surface of unit $\mathrm{C}$ is relatively even and lies under the youngest (probably Holocene) deposits of the Tehran playa (Unit D). In our study area, it lies unconformably over almost vertical beds of Unit A in the southern flank of the anticline, and over the B formation further north on the other limb of the fold. The $\mathrm{D}$ formation is the youngest of the preserved deposits in the Tehran plain.

\section{GEOLOGY AND GEOMORPHOLOGY OF THE PARDISAN FAULT-RELATED F O L D}

The east-west trending Pardisan fold is developed in alluvial deposits shed from the Alborz mountains in the north of Tehran (see
Section 2.3). The folding is visible in digital topography (Fig. 1c), though in modern satellite imagery it is largely obscured by building (Fig. 2). Much of the existing geomorphic mapping has hence relied on analysis of aerial photographs from a 1956 survey (e.g. Abbassi \& Farbod 2009, e.g. Fig. 3). In our study, we use existing remote-sensing and field surveys of the faulting, interpretation of aerial photographs, and also the interpretation of a new highresolution DEM constructed from high-resolution stereo satellite imagery. The assignment of the alluvial fan surfaces to Units B and $\mathrm{C}$ in our mapping differs in some places from those of earlier maps (e.g. Engalenc 1968; Landgraf 2010), particularly in that we assign a series of large, incised, though well-preserved alluvial fans as belonging to Unit $\mathrm{C}$, whereas these are sometimes included in Unit B. In the following discussion, we use the Unit names according to our own mapping.

The Pardisan fold is one of several left-stepping en-echelon fold segments within the Tehran plain (e.g. Fig. 1c). It is $\sim 12 \mathrm{~km}$ long, and has a general east-west trend that is oblique to the NTF. Near its western end it bends to acquire an NW-SE trend. In general, steeper beds are exposed in its southern flank, and an abrupt change in height is noticeable at the southern margin of the fold (e.g. Fig. 4a), consistent with it being underlain by a north-dipping thrust fault (e.g. Abbassi \& Farbod 2009; Landgraf 2010; Ritz et al. 2012). However, in the eastern part of the fold sediments in the northern limb are also locally steepened by back thrusting on the Davudieh and 'east-west' faults, which are both visible in the topography as abrupt breaks in the level of incision (Fig. 3b). The east-west fault outcropped in now covered road-cuttings as a thrust dipping $\sim 30^{\circ} \mathrm{S}$ (Tchalenko et al. 1974; Berberian 1976). Outcrops of Unit 'C' near the core of the anticline overlie tilted beds of Unit 'A' (Fig. 4b). The Unit ' $\mathrm{C}$ ' deposits show a pattern of growth strata suggesting uplift and tilting during the period of time in which Unit ' $\mathrm{C}$ ' was deposited.

Widespread faulting is documented within the fold (e.g. Tchalenko et al. 1974; Berberian 1976; Abbassi \& Farbod 2009). In addition to the south-dipping back thrusts described above, and other thrusts observed in rare outcrops (e.g. Fig. 4c), there are E$\mathrm{W}$ trending normal faults observed parallel to the fold axis (e.g. Figs 4d-f), and also a number of NW-SE trending faults that are oblique to the fold axis (Fig. 3). The longest of the NW-SE trending faults is the Bagh-e-Feyz fault, which is $\sim 3 \mathrm{~km}$ long (Tchalenko et al. 1974; Berberian 1976). The Bagh-e-Feyz fault offsets the surface of alluvial fans corresponding to Unit ' $\mathrm{C}$ ', and crosses the Farahzad river in the western part of the fold (Fig. 3b). The fault scarp is shown in detail in Fig. 3(c). Apparent right lateral displacements of small streams (for instance, streams $\mathrm{X}$ and $\mathrm{Y}$ that are highlighted in Fig. 3c) indicate a strike-slip component, and there is also a dipslip component, with uplift to the southwest. Another example of the NW-SE faults is the 'Television fault' which outcrops in road cuttings as a thrust (Tchalenko et al. 1974; Berberian 1976).

Aerial photographs from 1956 (Fig. 3) show that incision of the Unit ' $\mathrm{C}$ ' alluvial surface extends for a north-south extent of $\sim 3.5 \mathrm{~km}$, with the amount of incision increasing in the southern $\sim 1.5 \mathrm{~km}$ (Fig. 3). In order to measure the amount of warping and vertical displacement of alluvial surfaces across the Pardisan fold we constructed a DEM from stereo Pleiades satellite imagery. We used Pleiades tri-stereo imagery to construct an elevation model using the photogrammetry package in the software 'Erdas Imagine'. The pixel size is small enough compared to the lateral extent of roads and buildings that we obtained a dense point cloud of elevation estimates, even in urban areas (e.g. Fig. 5b). 

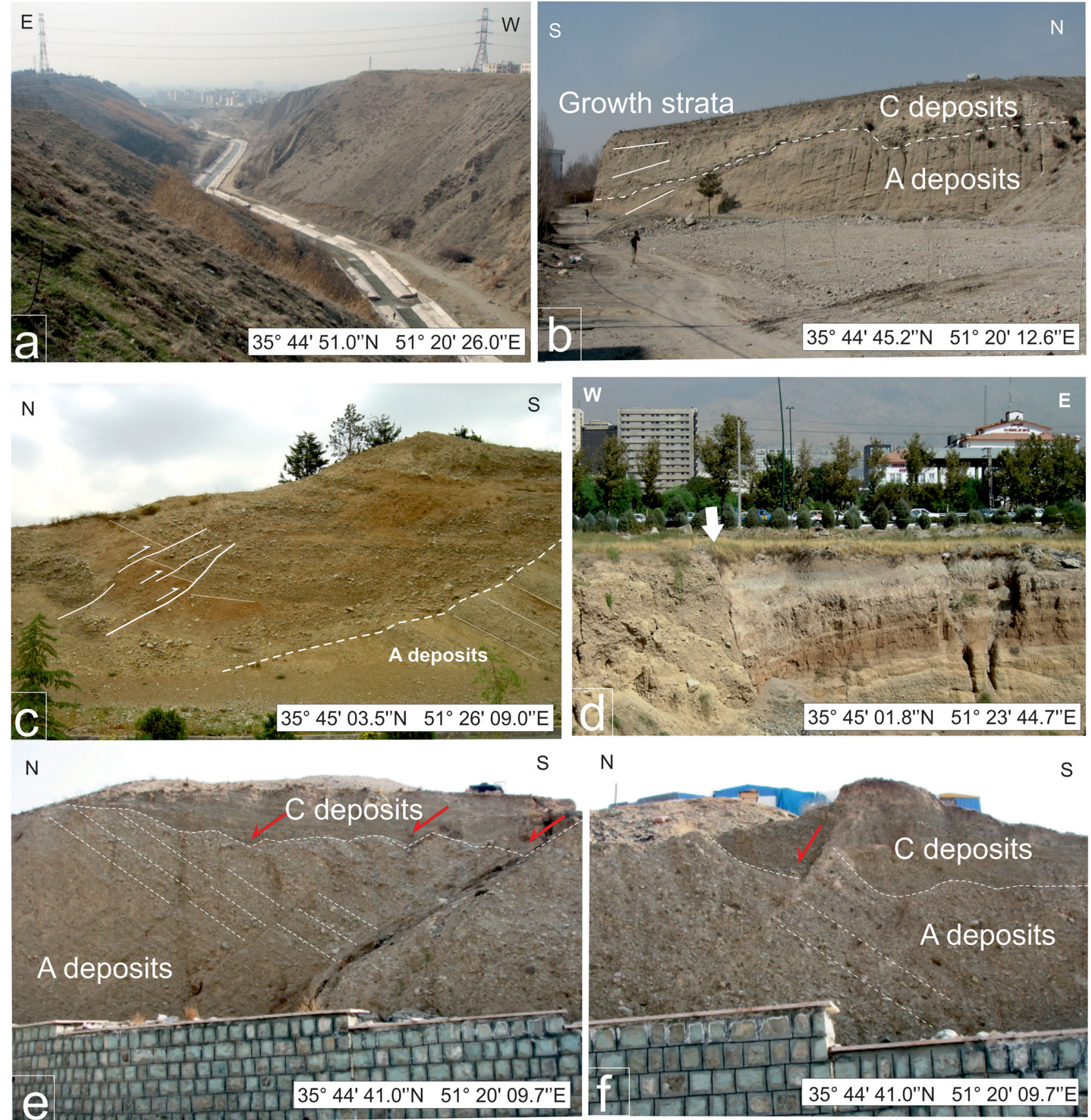

$\mathrm{N}$

Figure 4. Field photographs showing structural features exposed with the Pardisan fold (see Fig. 2 for approximate locations). (a) View south down the Farahzad river gorge from near the fold axis. The abrupt lowering in height at the southern margin of the fold is apparent from the buildings visible in the distance. (b) Beds of Unit ' $C$ ' unconformably overlying Unit ' $A$ ' deposits. Lower beds with Unit ' $C$ ' are tiled more than higher beds, showing growth during deposition. (c) An example of secondary thrust faulting in eastern part of the Pardisan fold. (d) Normal faulting in the central part of the Pardisan fold. $(e, f)$ Two views of normal faulting in the southern limb of the Pardisan fold, close to the Farahzad river.

A swath topographic section drawn N-S through the Pleiades DEM is shown in Fig. 6(a) (see Fig. 5 for the swath extents). The minimum values of elevation within the swath approximate the present-day base of the Farahzad gorge. The profile is smooth except for two bridges across the gorge (marked 'b' in Fig. 6a). The southern part of the swath profile is within the footwall of the Pardisan thrust, where no fluvial incision is visible either in the Pleiades DEM (Fig. 5b), or in the 1956 aerial photographs (Fig. 3c). Despite the absence of fluvial incision in the southern part of the profile, $\sim 50-60 \mathrm{~m}$ of offset is still visible between the maximum and minimum elevation envelope, which is likely to represent the building heights. The relatively smooth maximum envelope (except for in the northernmost parts of the profile) is indicative of a near-constant peak building height across this part of Tehran. Projecting the maximum topographic envelope from the footwall (southern) part of the profile northwards shows $\sim 20 \mathrm{~m}$ of overall height difference 


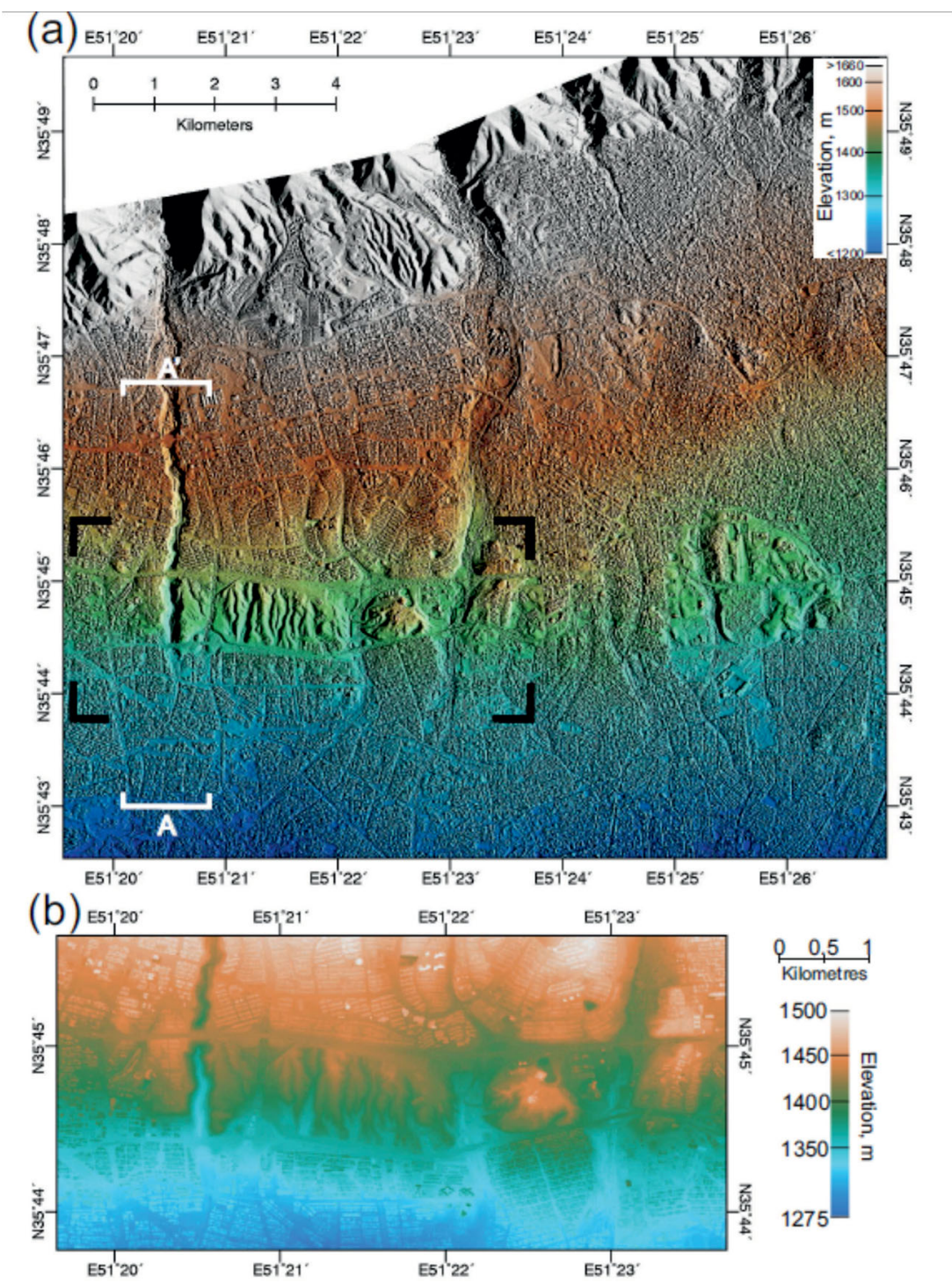

Figure 5. (a) Digital elevation model (DEM) produced from stereo Pleiades satellite imagery. A swath through the topography along the profile A-A is shown in Fig. 6. (b) A close-up view of the DEM along the SW part of the Pardisan anticline, see black rectangle in (a) for location. The extent of the view is similar to that in Fig. 3(c). The DEM is of sufficient resolution that the street plan and individual buildings are imaged. The abrupt change in height at the southern margin of the fold is apparent, as is the lack of fluvial incision south of it.

across the fold, increasing to $\sim 35 \mathrm{~m}$ in the southernmost $1.5 \mathrm{~km}$. The $35 \mathrm{~m}$ of offset at the southern margin of the fold is likely to be a minimum, as there are relatively few buildings within the southern $\sim 1.5 \mathrm{~km}$ of the fold, and so the maximum topographic envelope in this part may in fact be representative of the surface of the ground surface. In Figs 6(b) and (c), we show a field photograph and GPS profile along the Farahzad river gorge at the southern edge of the Pardisan fold. Here, the river has incised by up to $60 \mathrm{~m}$ into the Unit ' $\mathrm{C}$ ' alluvial surface, with incision dying away rapidly in the footwall.

The N-S magnitude and extent of uplift suggests a nearhorizontal detachment in the north, which acquires a northward dip (corresponding to the $\sim 20 \mathrm{~m}$ of uplift), and which then ramps steeply towards the surface at a depth of only 1-2 km (causing the increased uplift of 35-60 m). The 35-60 m of peak vertical displacement of the Unit ' $\mathrm{C}$ ' surface allows an opportunity to estimate the rate of vertical displacement and slip-rate, as investigated below
(Section 4). Our topographic profiles also show that the southern limit of the Pardisan fold is marked by a relatively steep scarp, with the warping of the Unit ' $\mathrm{C}$ ' surface occurring over a distance of no more than $\sim 200 \mathrm{~m}$. The short-wavelength of this tilting suggests that the underlying north-dipping thrust extends almost to the earth's surface. No outcrops of the primary thrust have been found, even in surveys that predate much of the urban cover (Rieben 1955; Tchalenko et al. 1974; Berberian 1976). It therefore appears that the primary fault tip may not break the surface, with slip instead accommodated by warping and secondary faulting over a zone of several hundred metres width. A similar behaviour was interpreted following the 1978 Tabas earthquake in eastern Iran (Zhou et al. 2016). Additional zones of secondary faulting occur further north within the fold, which are likely accommodation structures above bends in the underlying fault geometry or, in the case of the Baghe-Feyz and Television faults, oblique structures accommodating a strike-slip component. 

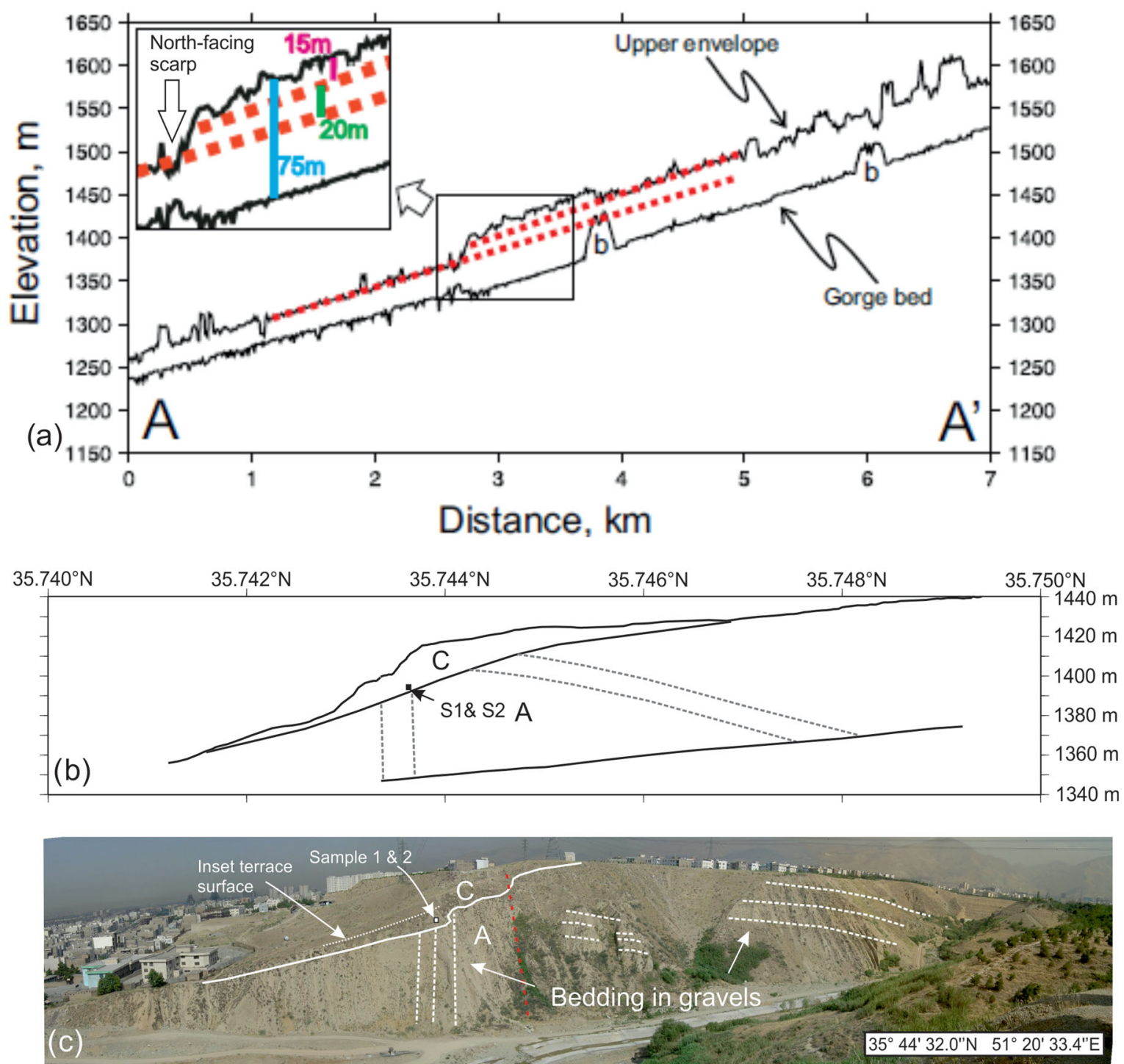

Figure 6. (a) Swath topographic profile along the line A-A' in Fig. 5(a), centred on the Farahzad river gorge. Both minimum and maximum elevation profiles are shown, with the minimum values representing the present-day river profile, and the maximum values representing the tops of the buildings (with particularly large structures showing up as short wavelength spikes). Locations marked ' $\mathrm{b}$ ' show where bridges disrupt the estimates of the lower envelope of the topography. There is a sharp vertical offset of the upper envelope of $\sim 35 \mathrm{~m}$ at the southern margin of the fold. Fluvial incision continues south of the fault. $\sim 1.5 \mathrm{~km}$ north of the main fault there is a north-facing scarp of $\sim 15 \mathrm{~m}$ height. (b) Kinematic GPS profile along the western margin of the Farahzad gorge showing the scarp at the southern margin of the Pardisan fold. Alluvial gravels of the Tehran Fm. (Unit C) overlie steeply tilted deposits of Unit A, and are themselves warped at the scarp. Dotted grey lines represent the bedding in alluvial gravels of Unit A. (c) Field photograph looking NW across the Farahzad gorge and the sedimentary exposures in the gorge wall. The vertical red line marks the approximate position of the Bagh-e-Feyz fault trace. The GPS profile in (b) came from the top of the gorge wall. Samples 1 and 2 were taken from near the base of the Unit C deposits.

\section{SLIP-RATE ESTIMATE}

Four samples were taken from alluvial deposits of Unit ' $\mathrm{C}$ ' (assigned to Unit B in the map of Landgraf 2010) exposed in the incised wall of the Farahzad river (Figs 6 and 7). The ' $\mathrm{C}$ ' formation is $\sim 20 \mathrm{~m}$ thick at the sample site, and was presumably deposited over a considerable length of time given the presence of growth strata in a nearby quarry (Fig. 4b). Sediments in the alluvial terrace are composed of coarse, poorly cemented, gravels sourced from both volcanic and non-volcanic rocks of the Alborz mountains in the north. The terrace deposits sit unconformably over older deposits of the Hezardarreh (Unit 'A') formation. Adjacent to the S1 and S2 sampling site the terrace is at height of about $40 \mathrm{~m}$ relative to the current profile of the drainage, but the terrace rises to $\sim 60 \mathrm{~m}$ above the river bed a short distance to the north (Figs $6 \mathrm{~b}$ and c).

Two of the samples (S1 and S2, Fig. 7) were collected from a shallow excavation into the terrace surface near the western edge of the Farahzad gorge (Figs $6 \mathrm{~b}$ and c, see Fig. 2 for approximate regional location). The samples were collected at depths of $\sim 1 \mathrm{~m}$ from the surface. However, on inspection of the geomorphology from the far side of the river (Fig. 6c), it is apparent that the surface is potentially of a later river terrace inset into the ' $\mathrm{C}$ ' deposits. Therefore, samples S1 and S2 may represent the age of the lower part of the ' $\mathrm{C}$ ' deposits. The $\mathrm{S} 1$ and S2 sample site is close to the outcrop of the Bagh-e-Feyz fault, which cuts obliquely through the fold. We do not consider it likely that the samples have been 


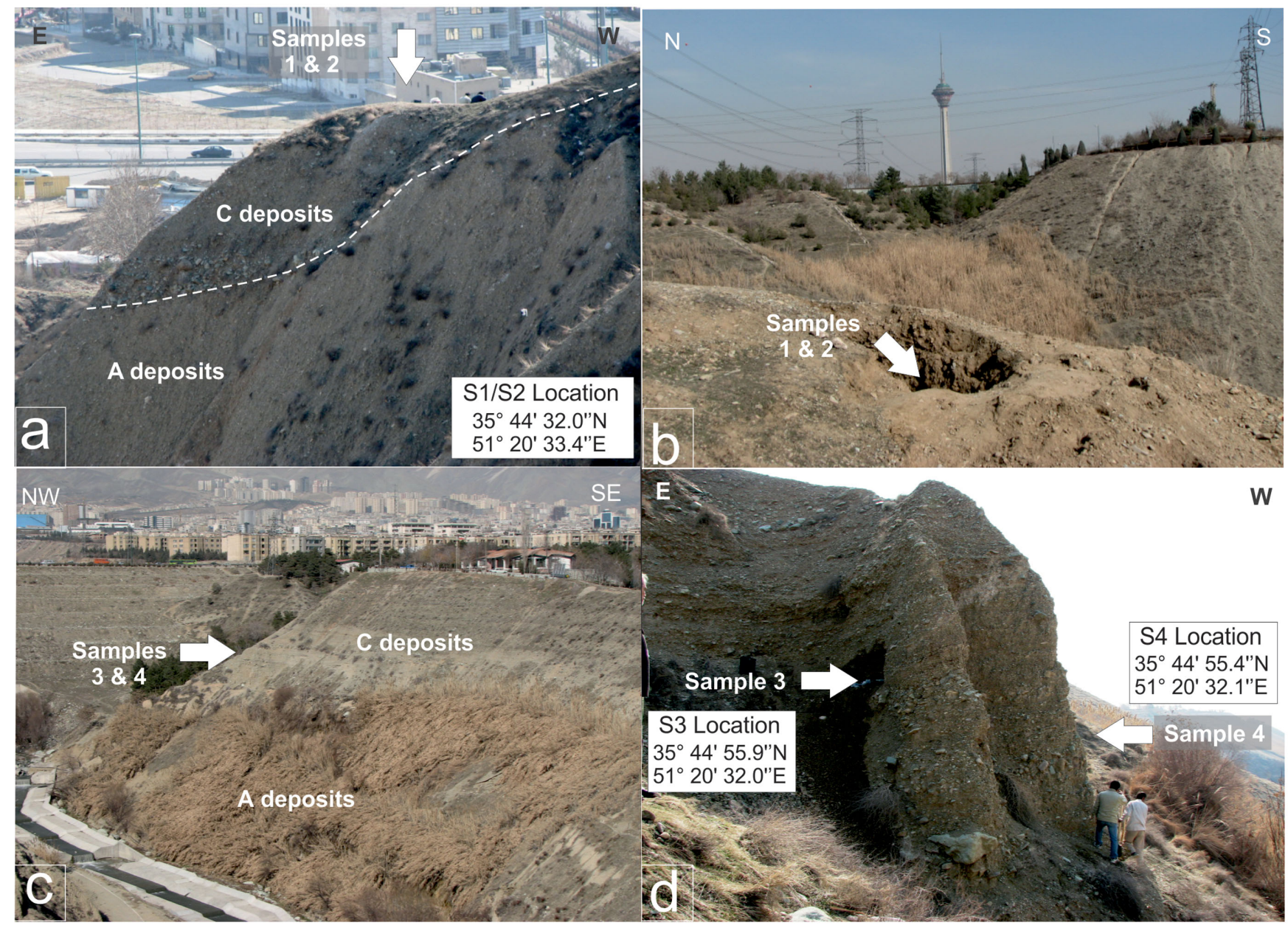

Figure 7. Field photographs showing the sample locations S1 to S4. (a,b) Samples S1 and S2 were taken from the wall of a shallow pit dug close to the western side of the Farahzad river gorge. The sample pit was dug in a place where most of the $\sim 20 \mathrm{~m}$ thickness of Unit ' $\mathrm{C}$ ' had already been removed by erosion, and hence S1 and S2 sampled the basal part of the unit. (c,d) Samples S3 and S4 were from a natural exposure of the Unit ' $\mathrm{C}$ ' gravels. The samples came from $\sim 6-7 \mathrm{~m}$ above the unconformable contact with older tilted deposits of Unit 'A'.

reworked by movement on the Bagh-e-Feyz fault as the gravel beds are continuous and have a typical morphology of fluvial/alluvial environments, rather than locally derived debris. Also, the sampled horizons do not incorporate the locally sourced altered clasts and thick cements from the adjacent Unit A horizons, suggesting that they were sourced from the main Farahzad river catchment.

The eastern samples of S3 and S4 were taken from natural exposures in the canyon wall (Fig. 7). S3 was extracted from a northwest facing part of the exposure, and S4 from a southwest facing part. The Unit ' $\mathrm{C}$ ' deposits are $\sim 20 \mathrm{~m}$ thick at this site, and the samples were taken $\sim 6-7 \mathrm{~m}$ above the angular unconformity with the B deposits and approximately $15 \mathrm{~m}$ below the ground level. The S4 sample was taken from about $1.5 \mathrm{~m}$ deeper layer relative to $\mathrm{S} 3$.

The samples were collected in metal tubes and Quartz (90$250 \mu \mathrm{m})$ size fractions was extracted from the samples under subdued red light at the Oxford Luminescence Laboratory, using the same preparation methods, instrumentation, and analysis protocols as those used by Fattahi et al. (2006). Organics and carbonates were removed with $\mathrm{HCl}$ and $\mathrm{H}_{2} \mathrm{O}_{2}$, and quartz was separated from heavy minerals with a density separation using sodium polytungstate (S.G. $2.7 \mathrm{~g} \mathrm{~cm}^{-3}$ ). A 50 min 40 per cent HF etches and sieving was used to remove heavily etched lighter minerals. Despite the predominantly volcanic source rocks of the southern
Alborz, sufficient Quartz grains were found for successful measurement. The De values were derived using the single aliquot regeneration protocol (Murray \& Wintle 2003) with four regeneration points and a recycling dose and an experimentally determined preheat temperatures of $260^{\circ} \mathrm{C}$ for $10 \mathrm{~s}$. Dose rates were determined using ICP-MS (Inductively Coupled Plasma Mass Spectrometry). Cosmic dose rates were determined following Prescott \& Hutton (1994).

Equivalent doses, annual dose and ages for all samples are presented in Table 1. Samples S1 and S2, which we interpreted as being from the basal part of Unit ' $\mathrm{C}$ ', yield ages of $\sim 35-38 \mathrm{ka}$, whereas samples $\mathrm{S} 3$ and $\mathrm{S} 4$, from $\sim 6 \mathrm{~m}$ higher in the stratigraphy, yield ages of $\sim 26-29 \mathrm{ka}$. We have no direct constraint on the age of the upper surface of Unit ' $\mathrm{C}$ ', which is $15 \mathrm{~m}$ above the $\mathrm{S} 3 / \mathrm{S} 4$ sampled level. Given that only $\sim 6 \mathrm{~m}$ of sediment were deposited over $\sim 9 \mathrm{ka}$ in the lower part of Unit ' $\mathrm{C}$ ', it is plausible that the upper surface dates from the Holocene (e.g. Vita-Finzi 1969), and may correspond with the $8-10 \mathrm{ka}$ alluvial fan abandonment that is widespread around northern and eastern Iran (e.g. Walker \& Fattahi 2011). In the following discussion, we consider the assumed case of $10 \mathrm{ka}$ as a minimum age, though as we shall see, this age yields rates that are too large to be plausible. Assuming that S3 and S4 are from the youngest sampled horizons allows us to place a maximum 
Table 1. Equivalent doses (De), annual dose rates (AD) and ages for samples S1 to S4.

\begin{tabular}{lcccccccc}
\hline Sample ID & De $(\mathrm{Gy})$ & \pm & $\mathrm{AD}\left(\mathrm{Gy} \mathrm{ka}^{-1}\right)$ & \pm & Age $(\mathrm{ka})$ & \pm & Latitude & Longitude \\
\hline S1 & 162.92 & 5.10 & 4.64 & 0.14 & 35.15 & 1.52 & N35 44 37.1 & E51 20 27.3 \\
S2 & 165.72 & 5.22 & 4.33 & 0.13 & 38.26 & 1.66 & N35 44 37.1 & E51 20 27.3 \\
S3 & 115.69 & 5.22 & 4.48 & 0.14 & 25.81 & 1.40 & N35 44 55.9 & E51 20 32.0 \\
S4 & 132.61 & 4.41 & 4.60 & 0.14 & 28.84 & 1.30 & N35 44 55.4 & E51 20 32.1 \\
\hline
\end{tabular}

limit on the upper surface of $\sim 25 \mathrm{ka}$. We also consider the case where $\mathrm{S} 1$ and $\mathrm{S} 2$ represent the maximum upper limit in age of the surface, at $\sim 35 \mathrm{ka}$.

The surface of Unit ' $C$ ' is displaced vertically by at least $35 \mathrm{~m}$ across the southern margin of the Pardisan fold. Using this $35 \mathrm{~m}$ of offset, an early Holocene abandonment age for the fan surface yields a throw-rate of at least $3.5 \mathrm{~mm} \mathrm{yr}^{-1}$, whereas an age of 25 ka yields a rate of $1.4 \mathrm{~mm} \mathrm{yr}^{-1}$, and an age of $35 \mathrm{ka}$ yields a rate of $1 \mathrm{~mm} \mathrm{yr}^{-1}$. We have no direct observations on fault dip, but the geomorphology suggests that it is relatively steep in the upper few kilometres. If the dip is $45^{\circ}$ the slip-rate on the fault would be at least $1.4 \mathrm{~mm} \mathrm{yr}^{-1}(35 \mathrm{ka})$, or $2 \mathrm{~mm} \mathrm{yr}^{-1}(25 \mathrm{ka})$, and could be as much as $4 \mathrm{~mm} \mathrm{yr}^{-1}(10 \mathrm{ka})$. Taking the maximum offset of $60 \mathrm{~m}$, the throw-rate increases to $1.7-6.0 \mathrm{~mm} \mathrm{yr}^{-1}$, and the slip-rate (with a dip of 45) between 2.4 and $8.5 \mathrm{~mm} \mathrm{yr}^{-1}$. The higher parts of the range of slip-rates are obviously too high, as they are greater than the measured GPS shortening across the whole Alborz range and its margins (e.g. Djamour et al. 2010). Importantly, however, the lower limits on slip-rate, irrespective of uncertainty in surface age and amount of displacement, are all at least $1 \mathrm{~mm} \mathrm{yr}^{-1}$.

\section{DISCUSSION}

The identification and characterization of active faults is essential for estimating earthquake hazard. Studies of recent Iranian earthquakes have demonstrated that many have occurred on previously unrecognized active faults (e.g. Talebian et al. 2004, 2006). In urban areas, the identification and characterization of active faults is further limited by human activity, and yet the combined use of historical aerial imagery and modern satellite-derived digital topography data can help to overcome those challenges. In Tehran, we were able to map out warped and offset alluvial surfaces using the aerial imagery, and to measure the amount of offset using the modern DEM. The remote-sensing analysis enabled the identification of suitable field sites from which we could obtain age control and hence slip-rates.

Tehran lies at the southern edge of the Alborz Mountains, which accommodate $\sim 5 \mathrm{~mm} \mathrm{yr}^{-1}$ of shortening at the present-day (e.g. Djamour et al. 2010). The prominent NTF, which runs along the range-front of the Alborz Mts., has a late Pleistocene slip-rate of only $\sim 0.3 \mathrm{~mm} \mathrm{yr}^{-1}$ (Ritz et al. 2012). Our results indicate that the Pardisan fold is related to an active north-dipping thrust fault with a slip-rate of at least $1 \mathrm{~mm} \mathrm{yr}^{-1}$. It hence appears that a large fraction of active shortening along the southern edge of the Alborz has migrated from the range-front fault onto young faults and folds within the Tehran basin. The Pardisan fault, and other segments along strike, are hence important structures within the regional tectonics, and are worthy of continued detailed study.

Our results do not give direct information on seismogenic potential of the Pardisan thrust fault, though several large historical earthquakes have epicentres near or within Tehran (Ambraseys \& Melville 1982; Berberian \& Yeats 1999). The fault systems north of Tehran are likely to have ruptured in earthquakes in 958, 1665 and 1830 (e.g. Berberian \& Yeats 1999). A recent paleoseismological study (Ritz et al. 2012) revealed that the NTF has caused at least seven earthquakes in the last $30000 \mathrm{yr}$, with two within the last $7.9 \pm 1.2 \mathrm{ka}$, which the authors speculate as the ruptures from the historical events in 312-280 B.C. and 1177 A.D. (Ritz et al. 2012). There are no candidate earthquakes as yet for the 855 A.D. event. No outcrops of the Pardisan thrust have been found, and it is likely from its topographic expression that the thrust tip ends a few hundred metres below the present ground surface, with slip on the fault accommodated by warping of the ground surface accompanied by widespread secondary faulting within the hanging wall (e.g. Berberian 1979; Zhou et al. 2016). The distribution of surface warping and rupturing has implications for the resilience of critical infrastructure. Detailed palaeoseismic investigation of secondary faulting in the hanging wall (e.g. Fig. 4) may also provide constraint on the timing of past slip events on the primary thrust and hence of its seismogenic potential (e.g. Li et al. 2015).

\section{CONCLUSIONS}

The results of our study provide the first quantitative estimate of slip-rate across the active faults within Tehran. We have shown that the Pardisan thrust has a slip rate of at least $1 \mathrm{~mm} \mathrm{yr}^{-1}$, much faster than the range-bounding NTF, and shows that is an important element in the accommodation of the $\sim 5 \mathrm{~mm} \mathrm{yr}^{-1}$ of $\mathrm{N}-\mathrm{S}$ shortening across the Alborz Mts. of northern Iran. We have also highlighted the usefulness of digital topographic models derived from stereo high-resolution optical satellite imagery for the study of tectonic geomorphology within urban regions. Slip on the Pardisan fault may dissipate in the upper few $100 \mathrm{~m}$ of Quaternary sediment cover, leading to distributed secondary faulting and warping that could have a large effect on critical infrastructure.

\section{H I G H L I G H T S}

- Thrust faults within the Tehran urban region are active and constitute a major earthquake hazard.

- Slip-rates in excess of $\sim 1 \mathrm{~mm} \mathrm{yr}^{-1}$ show that the faults beneath Tehran are important tectonically.

- Estimates of the geometry of the underlying fault help to describe the potential for ground rupture.

\section{ACKNOWLEDGEMENTS}

We thank the Geological Survey of Iran and COMET (Centre for the Observation and Modelling of Earthquakes, Volcanoes, and Tectonics) for their constant support of our collaboration. We are grateful to J-F. Ritz and A. Landgraf for their careful reviews and constructive comments. The fieldwork was completed while RAS was supported by a JRF position at Christ Church College, Oxford. Pleiades satellite data were purchased through the NERC-ESRC funded Earthquakes without Frontiers (EWF) consortium. 


\section{REFER E N CES}

Abbassi, M.R. \& Farbod, Y., 2009. Faulting and folding in quaternary deposits of Tehran's piedmont (Iran), J. Asian Earth Sci., 34(4), 522531.

Allen, M.B., Ghassemi, M.R., Shahrabi, M. \& Qorashi, M., 2003. Accommodation of late Cenozoic oblique shortening in the Alborz range, northern Iran, J. Struct. Geol., 25(5), 659-672.

Ambraseys, N.N. \& Melville, C.P., 1982. A History of Persian Earthquakes, Cambridge Univ. Press.

Berberian, M., 1976. Contribution to the Seismotectonics of Iran (Part IIIII), No. 39. Ministry of Industry and Mines, Geological Survey of Iran, Tectonic and Seismotectonic Section.

Berberian, M., 1979. Earthquake faulting and bedding thrust associated with the Tabas-e-Golshan (Iran) earthquake of September 16, 1978, Bull. seism. Soc. Am., 69(6), 1861-1887.

Berberian, M. \& Yeats, R.S., 1999. Patterns of historical earthquake rupture in the Iranian Plateau, Bull. seism. Soc. Am., 89(1), 120-139.

Berberian, M., Qorashi, M., Arzhang-Ravesh, B. \& Mohajer-Ashjai, A., 1985. Recent tectonics, seismotectonics, and earthquake-fault hazard study in the greater Tehran region: contribution to the seismotectonics of Iran, part V, Geological Survey of Iran Report 56, 316 (in Persian).

Berberian, M., Jackson, J.A., Qorashi, M., Khatib, M.M., Priestley, K., Talebian, M. \& Ghafuri-Ashtiani, M., 1999. The 1997 May 10 Zirkuh (Qaénat) earthquake $\left(\mathrm{M}_{\mathrm{W}}\right.$ 7.2): faulting along the Sistan suture zone of eastern Iran, Geophys. J. Int., 136(3), 671-694.

Copley, A., 2014. Postseismic afterslip 30 years after the 1978 Tabas-eGolshan (Iran) earthquake: observations and implications for the geological evolution of thrust belts, Geophys. J. Int., 197(2), 665-679.

Copley, A. \& Jackson, J., 2006. Active tectonics of the Turkish-Iranian plateau, Tectonics, 25(6), doi:10.1029/2005TC001906.

Copley, A. \& Jolivet, R., 2016. Fault rheology in an aseismic fold-thrust belt (Shahdad, eastern Iran), J. geophys. Res., 121, 412-431.

De Martini, P.M., Hessami, K., Pantosti, D., D’Addezio, G., Alinaghi, H. \& Ghafory-Ashtiani, M., 1998. A geologic contribution to the evaluation of the seismic potential of the Kahrizak fault (Tehran, Iran), Tectonophysics, 287(1), 187-199.

Djamour, Y. et al., 2010. GPS and gravity constraints on continental deformation in the Alborz mountain range, Iran, Geophys. J. Int., 183(3), 1287-1301.

Engalenc, M., 1968. Contribution a la Geologie, Geomorphologie, Hydrologie de la region de Tehran (Iran), C.E.R.H., 365 pp.

Engdahl, E.R., van der Hilst, R. \& Buland, R., 1998. Global teleseismic earthquake relocation with improved travel times and procedures for depth determination, Bull. seism. Soc. Am., 88, 722-743.

Fattahi, M., Walker, R., Hollingsworth, J., Bahroudi, A., Nazari, H., Talebian, M., Armitage, S. \& Stokes, S., 2006. Holocene slip-rate on the Sabzevar thrust fault, NE Iran, determined using optically stimulated luminescence (OSL), Earth planet. Sci. Lett., 245(3), 673-684.

Ghassemi, M.R., Fattahi, M., Landgraf, A., Ahmadi, M., Ballato, P. \& Tabatabaei, S.H., 2014. Kinematic links between the Eastern Mosha Fault and the North Tehran Fault, Alborz range, northern Iran, Tectonophysics, 622, 81-95.

Jackson, J.A., 2008. Surviving natural disasters, in Survival: The Survival of the Human Race, pp. 123-145, ed., Shuckburgh, E., Darwin College Lectures, Cambridge Univ. Press.

Jackson, J., Priestley, K., Allen, M. \& Berberian, M., 2002. Active tectonics of the South Caspian Basin, Geophys. J. Int., 148(2), 214-245.

Landgraf, A., 2010. Fault interaction at different time- and length scales: the North Tehran Thrust and Mosha-Fasham Fault (Alborz mountains, Iran), Unpublished PhD Thesis, University of Potsdam, Germany, 195 pp.

Landgraf, A., Ballato, P., Strecker, M.R., Friedrich, A., Tabatabaei, S.H. \& Shahpasandzadeh, M., 2009. Fault-kinematic and geomorphic observations along the North Tehran Thrust and Mosha Fasham Fault, Alborz mountains Iran: implications for fault-system evolution and interaction in a changing tectonic regime, Geophys. J. Int., 177(2), 676-690.
Li, T., Chen, J., Thompson, J.A., Burbank, D.W. \& Yang, X., 2015. Active flexural-slip faulting: a study from the Pamir-Tian Shan convergent zone, NW China, J. geophys. Res., 120(6), 4359-4378.

Mackenzie, D., Elliott, J.R., Altunel, E., Walker, R.T., Kurban, Y.C., Schwenninger, J.-L. \& Parsons, B., 2016. Seismotectonics and rupture process of the MW 7.1 2011 Van reverse-faulting earthquake, eastern Turkey, and implications for hazard in regions of distributed shortening, Geophys. J. Int., 206(1), 501-524.

Mousavi, Z., Walpersdorf, A., Walker, R.T., Tavakoli, F., Pathier, E., Nankali, H.R.E.A., Nilfouroushan, F. \& Djamour, Y., 2013. Global Positioning System constraints on the active tectonics of NE Iran and the South Caspian region, Earth planet. Sci. Lett., 377, 287-298.

Murray, A.S. \& Wintle, A.G., 2003. The single aliquot regenerative dose protocol: potential for improvements in reliability, Radiat. Meas., 37(4), $377-381$.

Nazari, H., Ritz, J-F., Salamati, R., Shafei, A., Ghassemi, A., Michelot, J.-L., Massault, M. \& Ghorashi, M. 2009. Morphological and palaeoseismological analysis along the Taleghan fault (Central Alborz, Iran), Geophys. J. Int., 178(2), 1028-1041.

Nazari, H., Ritz, J.F., Salamati, R., Shahidi, A., Habibi, H., Ghorashi, M. \& Bavandpur, A.K., 2010. Distinguishing between fault scarps and shorelines: the question of the nature of the Kahrizak, North Rey and South Rey features in the Tehran plain (Iran), Terra Nova, 22(3), 227-237.

Prescott, J.R. \& Hutton, J.T., 1994. Cosmic ray contributions to dose rates for luminescence and ESR dating: large depths and long-term time variations, Radiat. Meas., 23(2), 497-500.

Rieben, H., 1955. The geology of the Teheran plain, Am. J. Sci., 253(11), 617-639.

Ritz, J.F. et al., 2003. Determining the long-term slip rate along the Mosha Fault, Central Alborz, Iran. Implications in terms of seismic activity, in Proceeding of the 4th International Conference on Seismology and Earthquake Engineering, Vol. 1214, Tehran, Iran.

Ritz, J.F., Nazari, H., Ghassemi, A., Salamati, R., Shafei, A., Solaymani, S. \& Vernant, P., 2006. Active transtension inside central Alborz: a new insight into northern Iran-southern Caspian geodynamics, Geology, 34(6), 477480 .

Ritz, J.F. et al., 2012. Paleoearthquakes of the past 30000 years along the North Tehran Fault (Iran), J. geophys. Res., 117(B6), doi:10.1029/2012JB009147.

Solaymani Azad, S., Ritz, J.F. \& Abbassi, M.R., 2011. Left-lateral active deformation along the Mosha-North Tehran fault system (Iran): morphotectonics and paleoseismological investigations, Tectonophysics, 497(1), $1-14$.

Stöcklin, J., 1974. Northern Iran: Alborz Mountains, Geol. Soc. Lond. Spec. Publ., 4(1), 213-234.

Stöcklin, J. \& Setudehnia, A., 1971. Stratigraphic lexicon of Iran. Part 1: Central, North and East Iran, Geological Survey of Iran, Report (18).

Talebian, M. et al., 2004. The 2003 Bam (Iran) earthquake: rupture of a blind strike-slip fault, Geophys. Res. Lett., 31(11), doi:10.1029/2004GL020058.

Talebian, M. et al., 2006. The Dahuiyeh (Zarand) earthquake of 2005 February 22 in central Iran: reactivation of an intramountain reverse fault, Geophys. J. Int., 164(1), 137-148.

Tchalenko, J.S., Berberian, M., Iranmanesh, H., Bailly, M. \& Arsovsky, M., 1974. Tectonic framework of the Tehran region, Geological Survey of Iran Report 29.

Trifonov, V.G., Hessami, K.T. \& Jamali, F., 1996. West-trending oblique sinistral-reverse fault system in northern Iran, IIEES Spec. Publ., 75, Tehran, Iran.

Vernant, P. et al. 2004. Present-day crustal deformation and plate kinematics in the Middle East constrained by GPS measurements in Iran and northern Oman, Geophys. J. Int., 157(1), 381-398.

Vita-Finzi, C., 1969. Late Quaternary alluvial chronology of Iran, Geologische Rundschau, 58, 951-973.

Walker, R.T., 2006. A remote sensing study of active folding and faulting in southern Kerman province, SE Iran, J. Struct. Geol., 28(4), $654-668$. 
Walker, R.T. \& Fattahi, M., 2011. A framework of Holocene and Late Pleistocene environmental change in eastern Iran inferred from the dating of periods of alluvial fan abandonment, river terracing, and lake deposition, Quater. Sci. Rev., 30(9), 1256-1271.

Walker, R.T., Talebian, M., Saiffori, S., Sloan, R.A., Rasheedi, A., MacBean, N. \& Ghassemi, A., 2010. Active faulting, earthquakes, and restraining bend development near Kerman city in southeastern Iran, J. Struct. Geol., 32(8), 1046-1060.
Walker, R.T. et al., 2013. The 2010-2011 South Rigan (Baluchestan) earthquake sequence and its implications for distributed deformation and earthquake hazard in southeast Iran, Geophys. J. Int., 193(1), 349374

Zhou, Y., Walker, R.T., Hollingsworth, J., Talebian, M., Song, X. \& Parsons, B., 2016. Coseismic and postseismic displacements from the $1978 M_{\mathrm{W}}$ 7.3 Tabas-e-Golshan earthquake in eastern Iran, Earth planet. Sci. Lett., 452, 185-196. 